報 文

\title{
統一ラテックス試料によるゼーター電位及び安定性の共同測定
}

\author{
古沢邦夫*1） - 白井進之助*2) - 尾崎正孝*3) - 今野紀二郎*4）・北原文雄*4) \\ *1) 筑波大学化学系 ( \\ *2) 東北大学選鉱製練研究所 (干 980 仙台市片平 2-1-1) \\ *3) 横浜市立大学化学教室（广 236 横浜市金沢区瀬戸 22-2) \\ *4) 東京理科大学工業化学科（广162 東京都新宿区神楽坂 1-3)
}

\section{Collaborative Study of Zeta-potential and Stability of Latex Suspensions}

Kunio FURUSAWA*11, Shinnosuke USUI*2), Masataka OZAKI ${ }^{* 3)}$, Kijiro KON-NO*4), and Ayao KITAHARA*4)

*1), Department of Chemistry, The University of Tsukuba (1-1, Tennodai-1, Tsukuba-shi)

*2), Research Institute of Mineral Dressing and Metallurgy, Tohoku University (1-1, Katahira-2, Sendai-shi)

*3), Department of Chemistry, Yokohama City University (22-2, Seto, Kanazawa-ku, Yokohama -shi)

*4), Department of Industrial Chemistry, Science University of Tokyo (1-3, Kagurazaka, Shinjukuku, Tokyo)

Simultaneous measurements of zeta $(\zeta)$-potential and critical flocculation concentration (c.f. c.)s for two standard latex suspensions (Sample-A : Styrene/Nass copolymer latices, Sample-B : Amphoteric latices) were carried out so as to assess the reliability of each of these measurement techniques and find means for their improvement.

The $\zeta$-potential measurements were carried out at nine laboratories using different electrophoretic apparatus, which included the Rank Brother M-2, PEN KEM-501, PEN KEM-3000 and Malvern Zetasizer-F. The data from all the laboratories showed fair agreement. Elevated potential supply was found to increase the slope of the $\zeta$ vs. $\mathrm{pH}$ curve near the isoelectric point of sample-B.

The c.f.cs. of $\mathrm{KNO}_{3}, \mathrm{Mg}\left(\mathrm{NO}_{3}\right)_{2}$ and $\mathrm{La}\left(\mathrm{NO}_{3}\right)_{3}$ for sample-A, were determined simultaneously by a static method and the results compared with those determined by a kinetic method and dynamic light scattering (L.S.). The order of the magnitude of the values of c.f.c. can be expressed as follows : static method < L.S. technique < kinetic method. Furthermore, it was found that in determining the c.f.c., the solid concentration in the medium was important factor.

\section{1 序 論}

コロイド分散系の安定性やゼーター電位の測定は塗 料, インキ, 印刷, 食品など広範な工業分野に直接関係 するほか, 生体現象や環境問題とも密接に関係する重要 な問題である。また, 最近注目を集めている資源, エネ ルギー開発と有効利用においてもコロイド分散系の分 散, 凝集性が重要な役割を演じている場合が少なくない。 コロイド分散系の安定性を大きく支配するコロイド粒 子のゼータ一電位は, 本来測定条件さえ設定すれば分散
系固有の值として求められるはずである。しかし, 実際 には測定に使用する装置の種類や測定者の経験によって その絶対値は予想以上にばらつくことが多い。

日本油化学協会の界面電気測定法委員会では以前より ゼーター電位測定用標準コロイド試料の作製と測定法マ ニュアル設定の必要性を痛感し, 数次にわたり統一試料 について共同測定を実施した ${ }^{1)}$ ，2)。統一試料としては 二酸化チタンゾル, ポリスチレンラテックス, ヨウ化銀 ゾルなどが使用された。その結果はある試料（ヨウ化銀 ゾルなど）では比較的よい一致が得られたが, 多くの場 
合測定值は予想以上に分散し不成功に終わっている。国 外でも, 特に西ヨーロッパにおいて, “International Critical Tables” 作成の一貫として, オランダの J. Lyklema 教授を中心に各種コロイド試料のゼーター電 位の収集やその測定法の標準化が進められたが大きな成 果を得るに至っていない辛。

一方, コロイド分散系の安定性についてもその度合い を定める一定の尺度が見当たらず学会においても工業界 においても混乱をまねいているように思える。工業界で しばしば利用される安定性試験の慣用法は二, 三存在す るが4), その際重要な問題は用いるコロイド分散系に何 を選ぶかということである。調製の再現性や熟成効果に よる変質などの点から明らかに問題だと思われる分散系 が既存の方法では使用されている。また，コロイド系の 安定性は多面的な物性の総合効果で, 場合によっては一 つの試験法だけでなく, 複数の試験の結果を総括して判 定したり，試験のための新しい測定法を見いださなけれ ばならない場合もある。

本研究では, いくつかの民間企業研究所の協力を得て, 四つの大学のコロイド化学研究室が同時に統一試料によ る同一条件下でゼーター電位の測定と分散・凝集性の度 合い（電解質による臨界凝集濃度の違い）を調べた実験 結果を報告する。ゼーター電位の測定には現在市販され ている電気泳動装置のほとんどが使用され, 又臨界凝集 濃度の測定はより一般的な系の吸光度を比較する “静置 法 (Static Method)”が使用された。本研究により信頼 できるゼーター電位の値之分散・凝集の度合いがわかっ た標準コロイド分散系が誕生することになる が,これは今後行われるこの分野の実験デー タが一つの物差しで表示できるようになるの に役立つことのほかに、これらの共同実験を 通して電気泳動測定や分散・凝集性の測定法 における問題点が明確となり, 最適な測定法 マニュアルの設定に役立つものと思われる。

\section{2 実 験}

\section{$2 \cdot 1$ 試 料}

統一試料に用いるコロイド系は粒子径が均 一で物性の経時変化が少ない事が必要である が,ここではスチレンにスチレンスルホン酸 ナトリウム (NaSS) を少量共重合させたア ニオン性ラテックス(試料 A) ${ }^{5)}\llcorner$ Homola らの方法 ${ }^{6)}$ で調製されたスチレン主体の両性 ラテックス（試料 B) の二種類を使用した。 両試料に含まれるラテックス粒子の大きさ は,それぞれ $2 \mathrm{a}=250 \mathrm{~nm}$ (試料 A) と $2 \mathrm{a}=$ $230 \mathrm{~nm}$ (試料 B) で, いずれの試料も $\mathrm{D}_{\mathrm{w}} /$ $\mathrm{D}_{\mathrm{n}}<1.02$ の単分散性を有することが電子顕

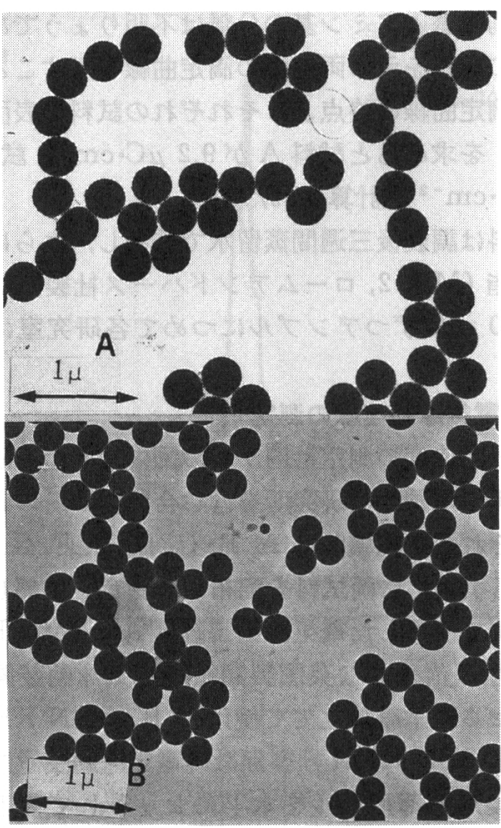

Fig.-1 Electron microphotographs of Sample-A and Sample-B.

微鏡による測定で確かめられた。Fig.-1 は試料 A 及び B の電子顕微鏡写真を示す。両試料粒子の表面電荷密 度 $\left(\sigma_{0}\right)$ はV Vanderhoff らの伝導度滴定法 ${ }^{7)}$ で測定さ れた。Fig. -2 に両試料の滴定曲線を示す。試料 A は典 型的な強酸型 ( $\mathrm{NaSS}$ の硫酸基によるものと思われる) の滴定曲線を示し, 試料 $\mathrm{B}$ は強酸基, 弱酸基及びアミ

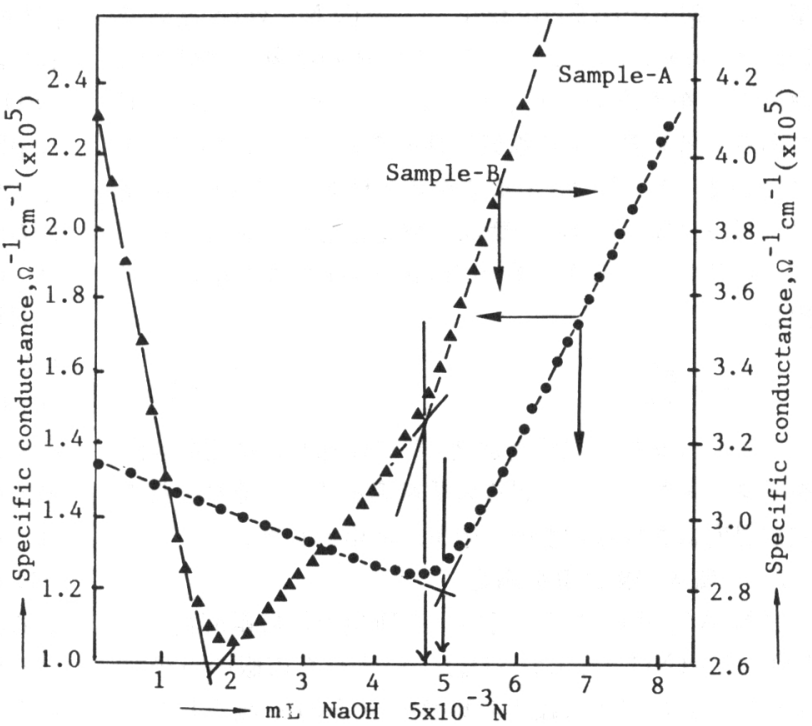

Fig.-2 Conductometric titration curves of Sample -A ( $)$ and Sample-B ( $\boldsymbol{\Delta})$ after ion exchange 
ン基 (弱酸基とアミン基の分離は不明りょうであるが) の三種の存在を示す両性型の洞定曲線を示すことがわか る。両滴定曲線の終点よりそれぞれの試料の表面電荷密 度 $\left(\sigma_{0}\right)$ を求めると試料 $\mathrm{A}$ が $9.2 \mu \mathrm{C} \cdot \mathrm{cm}^{-2}$, 試料 $\mathrm{B}$ が $134 \mu \mathrm{C} \cdot \mathrm{cm}^{-2}$ と計算された。

両試料は調製後三週間蒸留水で透析し, さらにイオン 交換樹脂 (MB-2, ロームアンドハース社製) で処理し た後, $50 \mathrm{~mL}$ ずつアンプルにつめて各研究室に送付し た。

\section{$2 \cdot 2$ 電気泳動速度の測定}

電気泳動速度の測定は四か所の国内民間企業研究所及 び一か所の外国公立研究所を含む合計九か所の研究機関

(それぞれの研究機関を A, B, C, D, E, F, G, H 及び I と命名する）に両試料を配布し，測定を依頼した。各 研究機関で使用した電気泳動装置は A; Rank Brother - M-2 型（代表的な英国製顕微鏡電気泳動装置で矩形 ガラスセルを垂直に立てて使用), B ; PEN KEM-500 型(米国 PEN KEM 社製顕微鏡電気泳動装置でプラス チック製矩形薄型セルを水平にセットして使用, レー ザー光を横から照射)，C；Rank Brother-M-2 型，D ; Laser Doppler 効果を利用した試作泳動装置（断面 $10 \mathrm{~mm} \times 3 \mathrm{~mm}$ のガラスセルを使用し, $\mathrm{He}-\mathrm{Ne} レ ー$ ザーを照射して泳動粒子による Laser Doppler 効果を FFT 法で解析),E ; PEN KEM-501 型, (PEN KEM -500 型の改良型で回転プリズム法を採用), F ; PEN KEM-3000 型（粒子の泳動速度を回転回折格子と FFT 法で解析するため, 電気泳動速度の平均值と共に 泳動速度の分布が求められる), G; PEN KEM-501 型, H ; Malvern Zetasizer-F (英国 Malvern 社製で Laser Doppler 法にもとづく電気泳動装置, 電気泳動 速度の分布も求められる), I ; Malvern Zetasizer $-F$ である。各装置による電気泳動速度の測定は試料 $\mathrm{A}, \mathrm{B}$ について $10^{-3} \mathrm{M} \mathrm{KCl}$ 水溶液中 $\mathrm{pH} 3 \sim \mathrm{pH} 10$ の範囲 ( $\mathrm{KOH}$ 亡 $\mathrm{HCl}$ 水溶液で調節) で測定した。また, ゼ一

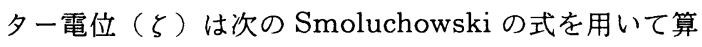
出した。

$$
u=\frac{\varepsilon E \zeta}{4 \pi \eta}
$$

ここでは $u$ は電気泳動速度, $E$ は印加した電圧の勾配 を示す。また $\varepsilon, \eta$ は媒質の誘電率と粘土でそれぞれの 測定温度における純水の文献值が使用された。

\section{$2 \cdot 3$ 臨界凝集濃度の測定}

試料 A を共通試料に用い, 三種類の無機電解質 $\mathrm{K}$ $\mathrm{NO}_{3}, \mathrm{Mg}\left(\mathrm{NO}_{3}\right)_{2}, \mathrm{La}\left(\mathrm{NO}_{3}\right)_{3} ;$; いずれも市販の特級試 薬を使用了に対する臨界凝集濃度 (c.f.c) を測定した。 まず, 8 10 mL の栓付き試験管に種々な濃度の電解質 水溶液 $5 \mathrm{~mL}$ とラテックス試料 $\mathrm{A}$ を適量加えて各系の 光 $(\lambda=550 \mathrm{~nm})$ の透過率が $5 \sim 10 \%$ になるように調節
した。これらの系をそれぞれ $30 \mathrm{~min}$ 転倒かくはんし, 更に 1 昼夜 $(24 \mathrm{~h})$ 静置した後, 光の透過率を測定して, 各電解質ごとに透過率対電解質濃度曲線を描き, その変 曲点より c.f.c. 值を求めて得られた結果の一致性を比較 した。上記のいわゆる“静置法”によるほか, 同系の c.f. c. 值は“凝集速度法”之“光散乱法”によっても求め られ, 静置法の值と比較された。凝集速度法ではユ二オ ン技研社製サンプル混合器 $(\mathrm{MX}-7)$ で, ごく希薄なラ テックス分散液 $1.5 \mathrm{~mL}$ と同量の電解質溶液を急速混合 し光学密度 $(A)$ の時間変化の初期勾配〔その逆数の対 数 $\log (\mathrm{d} t / \mathrm{d} A)_{t \rightarrow 0}$ は分散系の安定度比 $(W)$ の対数 $\log$ $W$ に比例する〕を分光光度計 (JASCO-UVIDEC410)で測定した。また, 光散乱法では種々な電解質濃 度下での分散粒子の大きさを動的光散乱法で直接測定 し, 粒子径対電解質濃度曲線の変曲点より c.f.c. 值を求 めた。この際光散乱装置としては Nicom-Model 200 型粒子サイザーを使用した。

その他各測定者が静置法で求めた c.f.c. における分散 粒子のゼー夕一電位を電気泳動法で求め, それらの值と c.f.c. 值を用いて凝集臨界点での粒子間相互作用ポテン シャル曲線を描き, 凝集臨界点の状態を満足する Hamaker 定数 (A) をグラフィカルに決定し，それら の $\mathbf{A}$ 值によ゙の程度の一致性が得られるか検討した。

\section{3 結果及び考察}

\section{$3 \cdot 1$ ゼーター電位の共同測定}

Fig. -3 に試料 A 及び B について共同測定した $\zeta 一$ 電位対 $\mathrm{pH}$ 曲線の代表例を示す。試料 $\mathrm{A}$ は測定された $\mathrm{pH}$ 域ではほとんどゼーター電位の変化を示さない。こ れは試料 A の表面極性基が NaSS に由来した強酸型の $-\mathrm{SO}_{3}^{-}$基によることを示すものである。一方, 試料 $\mathrm{B}$ は pH 6.5 8 の範囲でゼーター電位は正から負へ変化 している。Homola の方法で調製したラテックス粒子 の表面には触媒 (過硫酸カリ) からの $-\mathrm{SO}_{3} \mathrm{H}$ 基のほか に $-\mathrm{CO}_{2} \mathrm{H}$ 基と $-\mathrm{NH}_{2}$ 基が共存し, 特に $-\mathrm{CO}_{2} \mathrm{H}$ 基と $-\mathrm{NH}_{2}$ 基は媒質の $\mathrm{pH}$ で解離が変わるので電荷の反転 が起こるものと思われる。Table-1 は試料 A について

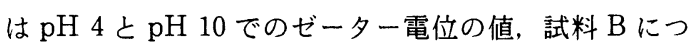
いてはゼーター電位がゼロになる $\mathrm{pH}$ 值 $\left(\mathrm{pH}^{0}\right.$ と略記) の全測定データーが示されている。試料 $\mathrm{A}$ は $\mathrm{pH} 4$ で は $-44 \mathrm{mV}<\zeta<-62 \mathrm{mV}$ の範囲に, また $\mathrm{pH} 10$ では $-44 \mathrm{mV}<\zeta<-65 \mathrm{mV}$ の範囲に分散していることがわ かる。試料 $\mathrm{B}$ の $\mathrm{pH}^{0}$ は $\mathrm{pH}$ 6.5 8 の範囲に分散して いるが，本実験が無緩衝剤下で行われた点を考慮にいれ るとこの程度のばらつきは妥当なものであろう。ただ D (Laser Doppler 法) 及び F(PEN KEM-3000)の $\zeta$ 対 $\mathrm{pH}$ 曲線における $\mathrm{pH}^{0}$ 近傍での勾配が異常に大き く (Fig. -3 参照), 他のデー夕の傾向と異なることが 


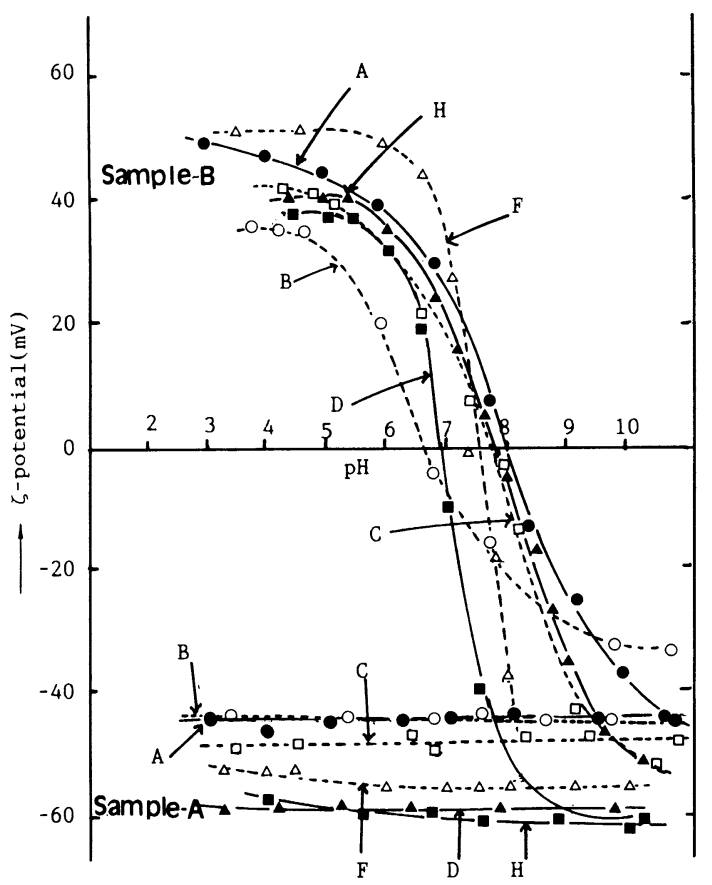

A : Rank brother-M-2, B : PEN KEM-500, C : Rank brother-M-2, D : Laser Doppler method, F : PEN KEM-3000, H : Malvern zetasizer-F.

Fig. $-3 \quad \zeta$-potential vs. pH curves of Sample-A and Sample-B.

観測される。両測定法では一般顕微鏡電気泳動法に比べ て印加電圧が大きく，一般の場合の 10 倍以上の高圧下 で測定された点は留意すべきである。さらに試料 $\mathrm{A} に$ おいても Laser Doppler 効果を用いた方法では高い ゼー夕電位を示す傾向（Table-1参照）がみられる。

Fig. -4 は $\mathrm{F}(\mathrm{PEN}$ KEM-3000) と $\mathrm{H}($ Malvern Zetasizer-F) で求めた試料 $\mathrm{A} の 1 \times 10^{-3} \mathrm{M} \mathrm{KCl}$ 水溶液 中での電気泳動速度 $(u)$ の分布を比較している。F で 求めた結果 $($ Fig. - - - a ) は分布幅は狭く粒子のゼーター 電位は均一に見えるが，H で求めた Fig. $-4-\mathrm{b}$ では幅 の広い分布曲線を示す。さらに $\mathrm{H}$ による結果は電解質 の種類や $\mathrm{pH}$ で顕著に分布曲線は变化しないが, $\mathrm{F}$ で求 めると著しい変化が観察された。Fig.-5 は F で求めた 試料 $\mathrm{A} の 1 \times 10^{-3} \mathrm{M} \mathrm{Mg}\left(\mathrm{NO}_{3}\right)_{2}$ 水溶液中での分布曲 線を示す。Fig. -4-a と比較すると同一試料とは思えぬ

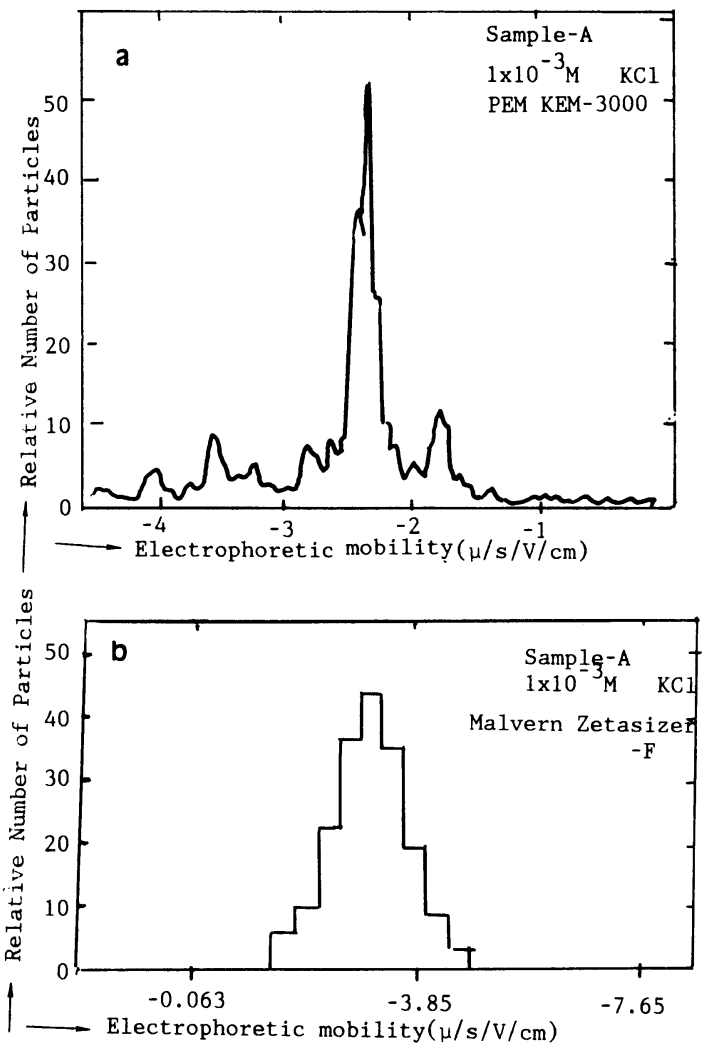

Fig.-4 Mobility histograms of Sample-A in $10^{-3}$ $\mathrm{M} \mathrm{KCl}$ measured by PEN KEM-3000 (a) and Malvern zetasizer-F (b).

ほど複雑な分布曲線を示している。これらの結果はコロ イド粒子は添加する電解質の種類によってゼーター電位 の分布を変化させることを暗示している。いずれにして も $\mathrm{F}$ の方が $\mathrm{H}$ に比べて条件に応じて鋭敏に電気泳動速 度の分布の变化を反映することがわかった。

\section{2 臨界凝集濃度の共同測定}

Fig.-6 は静置法で c.f.c. 值を求めたときの光の透過 率対電解質濃度曲線の一例を示す。ここには示さないが, 多くの測定の結果から試料液の初期濃度を透過率 10\% 程度に調節したものを用いることによって, 電解質濃度 による系の透過率変化が顕著となり, c.f.c. 值が明確に 求められることがわかった。Table-2 に三種類の電解 質 $\left[\mathrm{KNO}_{3}, \mathrm{Mg}\left(\mathrm{NO}_{3}\right)_{2}, \mathrm{La}\left(\mathrm{NO}_{3}\right)_{3}\right]$ を用いて求めら

Table-1 $\zeta$-Potentials of Sample-A and isoelectric points of Sample-B.

\begin{tabular}{c|c|c|c|c|c|c|c|c|c|c}
\hline & & \multicolumn{1}{c|}{ A } & \multicolumn{1}{c|}{ B } & C & D & E & F & G & H & I \\
\hline Sample-A & $\mathrm{pH} 4$ & -44.0 & -45.0 & -48.0 & -57.7 & -58.0 & -53.0 & -62.0 & -59.0 & -44.5 \\
\cline { 2 - 10 }$(\zeta ; \mathrm{mV})$ & $\mathrm{pH} 10$ & -44.0 & -45.0 & -48.0 & -60.5 & -58.0 & -54.0 & -65.0 & -62.0 & -46.0 \\
\hline Sample-B & $\mathrm{pH}^{0}$ & 8.0 & 6.6 & 7.8 & 6.8 & 7.1 & 7.6 & 8.2 & 7.8 & 6.5 \\
\hline
\end{tabular}




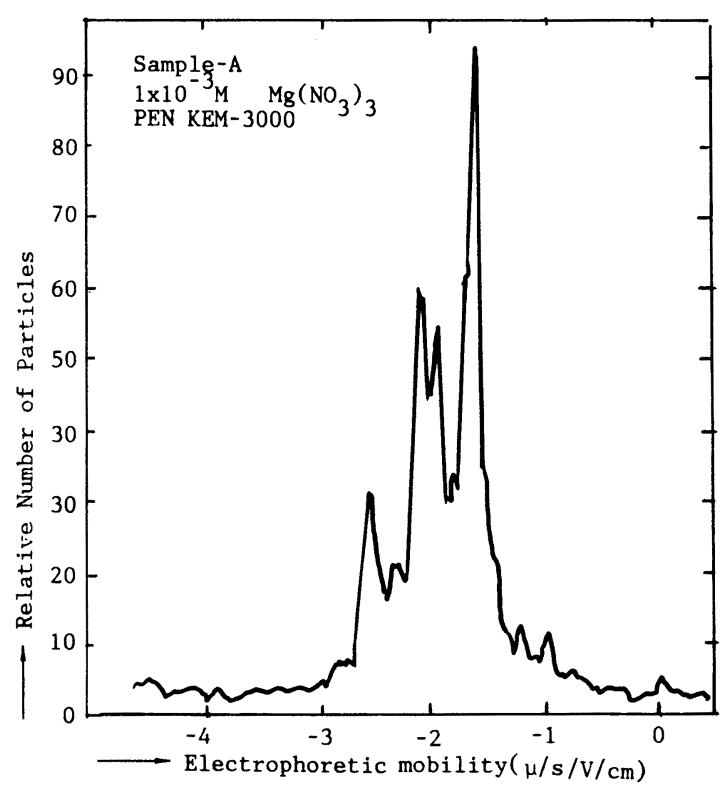

Fig.-5 Mobility histogram of Sample-A in $10^{-3}$ $\mathrm{M} \mathrm{Mg}\left(\mathrm{NO}_{3}\right)_{2}$ measured by PEN KEM3000 .
れた各測定者の c.f.c. 值が示されている。いずれの場台 もc.f.c. 值は陽イオン価の増加と共に減少しており,こ こで用いた分散系（試料 A) は Schultze-Hardy 型の 凝集 ${ }^{9)}$ を取ることがわかる。このうち，特に A, B, D が求めた c.f.c. 值はいずれの電解質の場合もよい一致を 示すが, $\mathrm{C}$ の結果は全体的に大きな值を示し他の值とず れている。C は測定に際し極端に希釈した試料液を用い たことが後から判明したが, 今後の共同測定では試料液 の濃度を更に厳密に規定してから行わなければならない ことを示唆するものである。

Fig. -7 に凝集速度法で c.f.c. 值を求めた際の $\log$ $(\mathrm{d} t / \mathrm{d} A)_{t \rightarrow 0}$ 対電解質濃度曲線が示されている。静置法 に比べてより明確な変曲点として c.f.c. 值が決定できる ことがわかる。また, 凝集速度法で求められた c.f.c. 值 は静置法による值に比べ一けた以上も大きな值が得られ た。これは両測定法の性格の違いによるもので, 静置法 では電解質イオンによる粒子表面への吸着平衡が成立し ているが, 凝集速度法では主に対イオンによる電気二重 層の圧縮効果によって凝集するためである。このような 静置法と凝集速度法による c.f.c. 值の違いの傾向は他の コロイド系においても見いだされている ${ }^{10)}$ 。

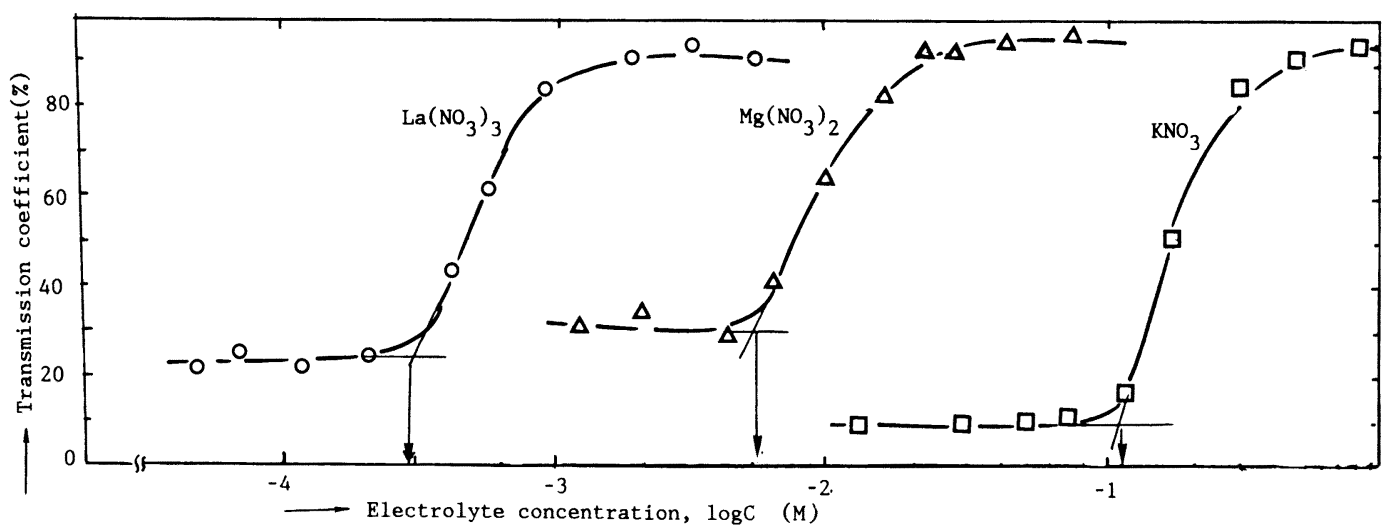

$\mathrm{KNO}_{3}, \triangle ; \mathrm{Mg}\left(\mathrm{NO}_{3}\right)_{2}, \mathrm{O} ; \mathrm{La}\left(\mathrm{NO}_{3}\right)_{3}$

Fig.-6 Transmission coefficient us. electrolyte concentration curves.

Table-2 Critical flocculation concentration (c.f.c.) and some related data.

\begin{tabular}{l|l|l|l|l|l|l|l|l|l}
\hline & \multicolumn{3}{|c|}{$\mathrm{KNO}_{3}$} & \multicolumn{3}{c|}{$\mathrm{Mg}\left(\mathrm{NO}_{3}\right)_{2}$} & \multicolumn{3}{c}{$\mathrm{La}_{\left(\mathrm{NO}_{3}\right)_{3}}$} \\
\cline { 2 - 10 } & c.f.c. $(\mathrm{M})$ & $\zeta(\mathrm{mV})$ & $\mathbf{A}(\mathrm{erg})$ & c.f.c. $(\mathrm{M})$ & $\zeta(\mathrm{mV})$ & $\mathbf{A}(\mathrm{erg})$ & c.f.c. $(\mathrm{M})$ & $\zeta(\mathrm{mV})$ & $\mathbf{A}(\mathrm{erg})$ \\
\hline $\mathrm{A}$ & $1.1 \times 10^{-1}$ & -40 & $2 \times 10^{-13}$ & $4.2 \times 10^{-3}$ & -35 & $4.4 \times 10^{-13}$ & $1.8 \times 10^{-4}$ & -19 & $4.5 \times 10^{-13}$ \\
$\mathrm{~B}$ & $1.01 \times 10^{-1}$ & -39.4 & $2.4 \times 10^{-13}$ & $4.6 \times 10^{-3}$ & -20.9 & $1.7 \times 10^{-13}$ & $2.2 \times 10^{-4}$ & -3.7 & $1.6 \times 10^{-14}$ \\
C & $2.0 \times 10^{-1}$ & -28 & $1.0 \times 10^{-13}$ & $2.0 \times 10^{-2}$ & -23 & $1.0 \times 10^{-13}$ & $3.0 \times 10^{-4}$ & -11 & $2.0 \times 10^{-13}$ \\
$\mathrm{D}$ & $0.7 \times 10^{-1}$ & -41 & $3.0 \times 10^{-13}$ & $5.4 \times 10^{-3}$ & -35 & $4.0 \times 10^{-13}$ & $1.9 \times 10^{-4}$ & -14 & $2.0 \times 10^{-14}$ \\
A $^{*}$ & & & & $5.6 \times 10^{-2}$ & -15 & $1.2 \times 10^{-13}$ & & & \\
D* & & & $1.05 \times 10^{-2}$ & & & & & \\
\hline
\end{tabular}

$\mathrm{C}$; data measured in diluted dispersed system.

$\mathrm{A}^{*}$; data measured by kinetic method.

$\mathrm{D}^{*}$; data measured by dynamic light scattering technique. 


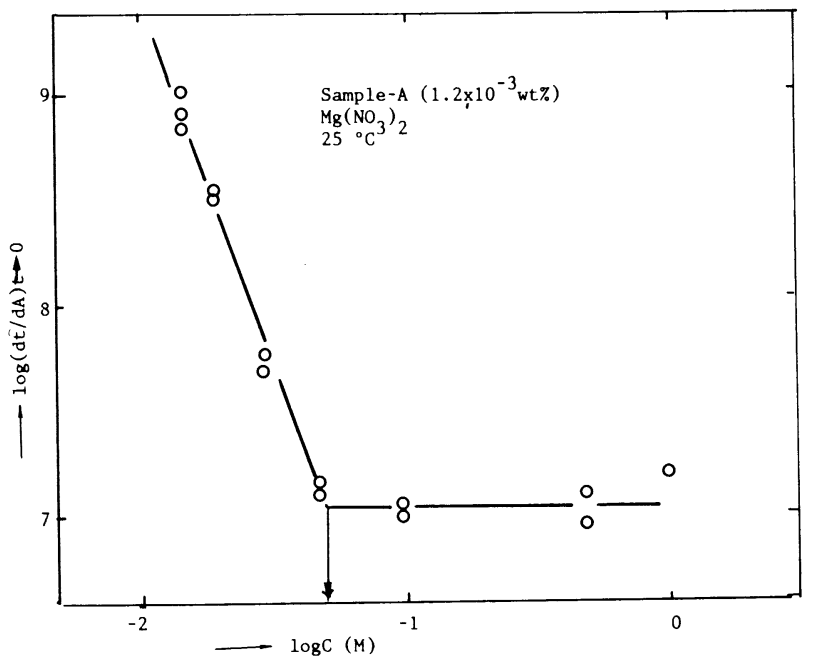

Fig. -7 Dependence of $\log (\mathrm{d} t / \mathrm{d} A)$ on the concentration of $\mathrm{Mg}\left(\mathrm{NO}_{3}\right)_{2}$. The break indicated by arrow gives the c.f.c.

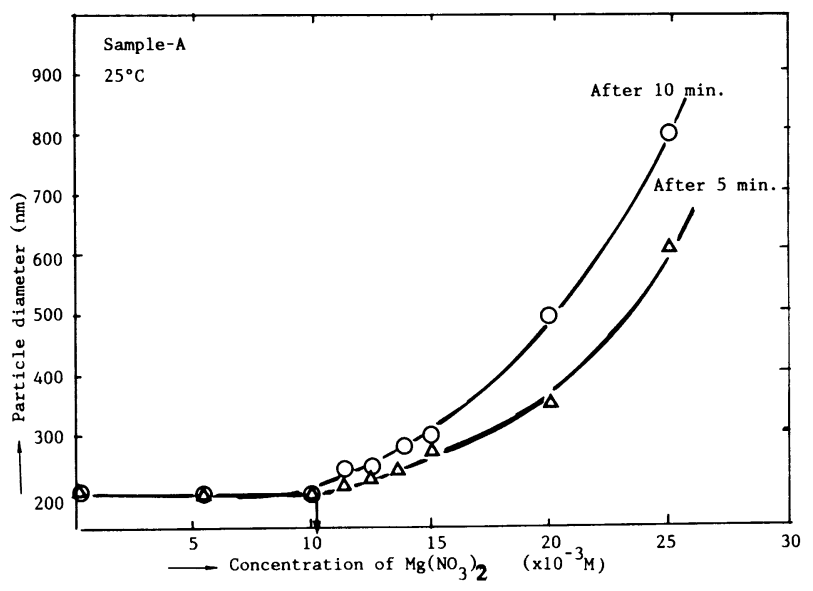

Fig.-8 Relation between the concentration of $\mathrm{Mg}\left(\mathrm{NO}_{3}\right)_{2}$ and particle diameters at 5 and $10 \mathrm{~min}$. after adding the electrolyte. The particle diameters at each stage were determined by dynamic light scattering technique.

Fig. -8は動的光散乱法で測定したいろいろな電解質 濃度下の粒子径とその濃度の関係を示す。電解質濃度を 添加 $5 \mathrm{~min}$ 後と $10 \mathrm{~min}$ 後の関係がプロットされてい るが時間の経過で粒子がよ゙んどん大きくなり凝集が進行 して行くのがわかる。しかしいずれの曲線からも凝集が 開始する電解質濃度は $1 \times 10^{-3} \mathrm{M}$ で一致している。ま た,この光散乱法で決定した c.f.c. 值は静的法による値 と凝集速度法による值の中間になることがわかる。凝集 速度法が凝集開始の初期状態を取り扱っているのに対
し, 静置法は電解質添加一昼夜後の物性を比較

していることを考えると，ここで得られたc.f. c. 值の大きさの順序は妥当なものといえよう。 このようにコロイド系の c.f.c. 值は測定法の違 いによって明らかに異なったものとなり，ここ に測定法の統一化や評価法を規定する必要がい われるゆえんがある。

$3 \cdot 3$ c.f.c. でのゼーター電位測定と Hamaker 定数の決定

D. - L. -V.-O. 理論 ${ }^{111}$ によるとコロイド粒 子間の相互作用は電気二重層の重なりによる静 電的反発ポテンシャルエネルギーと Van der Waals 引力エネルギーの和で表され，球 状粒子の系には次式が適用できることが知られ ている。

$$
V t=\frac{\varepsilon a \phi_{0}{ }^{2}}{2} \ln \{1+\exp (-\kappa H)\}-\frac{\mathbf{A}}{12} \cdot \frac{a}{H}
$$

ここで $\varepsilon$ は水の誘電率, $a$ は球状コロイド粒子 の半径, $\psi_{0}$ は粒子の表面電位, $\kappa$ は対イオン 濃度を含む定数で, Debye 定数と呼ばれる。 また A は Hamaker 定数と呼ばれるコロイド 特有の定数であり, $H$ は粒子間距離を表す。い ま, 試料 $\mathrm{A} の \mathrm{KNO}_{3}$ に対する c.f.c. 值と c.f. c. での $\zeta$ 電位を $\phi_{0}=\zeta$ と置いて式 (2) を用い 相互作用ポテンシャル曲線 ( $V t$ 対 $H$ 曲線) を 描くとポテンシャルの極大（凝集の障壁）は零 にならねばならない。

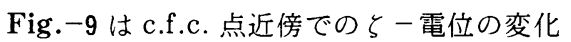
を示したもので，これらの曲線より各電解質の c.f.c. での $\zeta$ 電位が求められる。Fig.-10 は $\mathrm{KNO}_{3}$ の c.f.c. での $V t$ 対 $H$ 曲線がいろい ろな $\mathbf{A}$ 一值を用いて描かれている。凝集の難解 点では $V t=0$ と $\mathrm{d} V t / \mathrm{d} H=0$ の条件が満たされ るので曲線 (3) が妥当であり, 従って Hamaker 定数は $\mathbf{A}=2.4 \times 10^{-13} \mathrm{erg}$ 亡決定される。 Table-2 には各測定者が求めた c.f.c. での 一電位と上記の方法で決定した Hamaker 定 数の值も示されている。本来 $\mathbf{A}$-值は物質特性 の定数でコロイド系が決まれば電解質の種類に よらず一定值を示すはずである。ここで求めた值は必ず しも一定でなく，特に $\mathrm{La}\left(\mathrm{NO}_{3}\right)_{3}$ を用いた場合に大き な変化が認められる。これはc.f.c. 值の測定における誤 差とら一電位の測定誤差が相乗して現れたものである が，これを一致させるためには実験条件のより厳密な規 定と测定法の更なる改良が必要であろう。ただ，Table -2において希釈分散系で c.f.c. 值を求めた C の結果が いずれの電解質の場合でもほぼ一定の $\mathbf{A}$ 一値をあたえて おり,この点は今後の研究計画を立案する上で充分考虑 


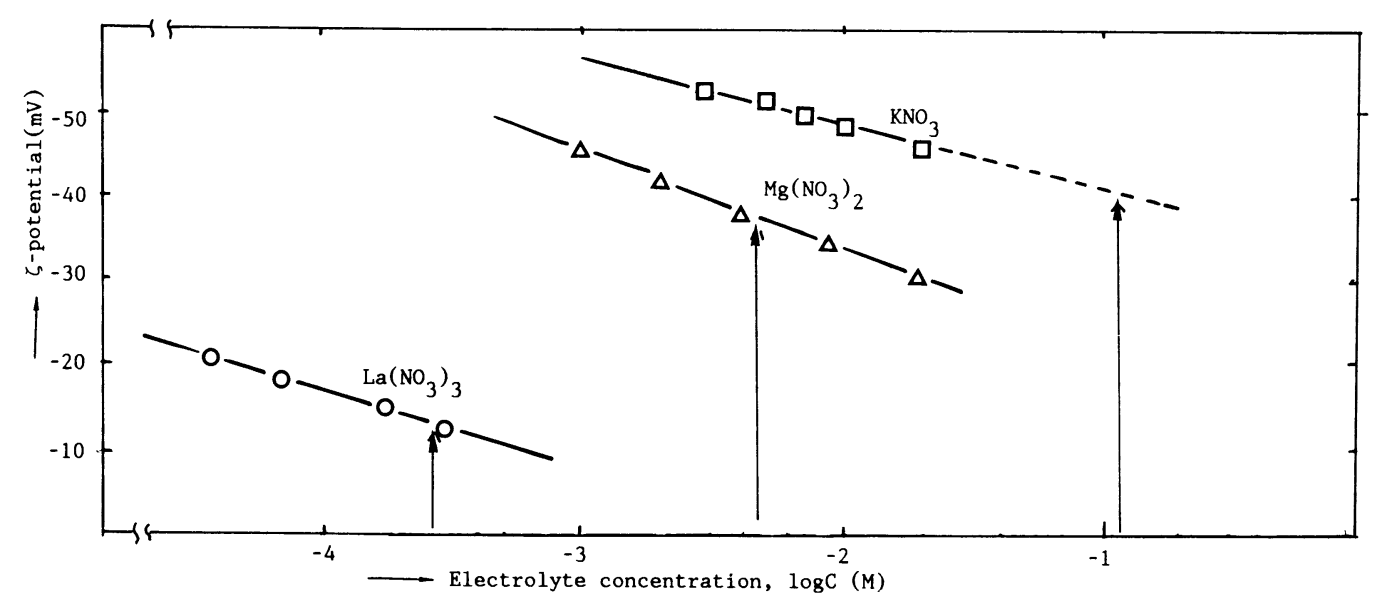

$; \mathrm{KNO}_{3}, \triangle ; \mathrm{Mg}\left(\mathrm{NO}_{3}\right)_{2}, \mathrm{O} ; \mathrm{La}\left(\mathrm{NO}_{3}\right)_{3}$

Fig. $-9 \quad \zeta$-potentials of Sample-A as function of electrolytes.

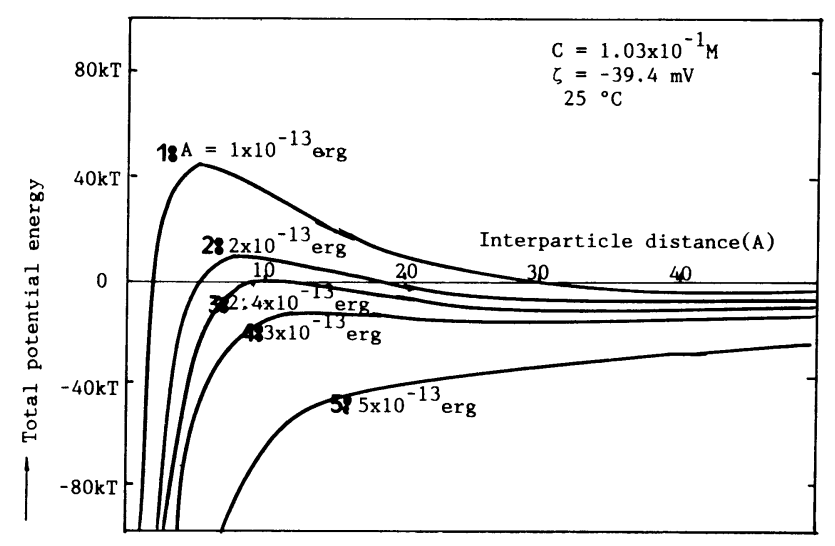

Fig.-10 The curves of interaction potential between two particles for $\mathrm{KNO}_{3}$ (1: $\mathbf{A}=1 \times 10^{-13}$ erg, $2: \mathbf{A}=2 \times 10^{-13} \mathrm{erg}, 3: \mathbf{A}=2.4 \times 10^{-13}$ $\mathrm{erg}, 4: \mathbf{A}=3 \times 10^{-13} \mathrm{erg}, 5: \mathbf{A}=5 \times 10^{-13}$ erg).

すべき点と思われる。

\section{4 ま と}

Styrene/NaSS 共重合ラテックス及び両性ラテック スを共通試料に選び 9 種の研究機関によるら電位測定と 4 種の研究機関による c.f.c. の同時測定を行い次のよう な結論を得た。

$\zeta$ 一電位の測定には現在市販されている主な電気泳動 装置のすべてが含まれているので, 各装置の特徴之性能 を比較する上でも興味が持たれたが，いずれも両試料に 対しほぼ満足すべき結果を与え, 装置間のデータのばら つきは比較的小さいものであった。ただ，一般の顕微鏡 電気泳動法に比べ約 10 倍高い印加電圧下で測定を行う
Laser Doppler 法や PEN KEM-3000 による 値は等電位点近傍で他の装固によるものとやや 違った傾向を呈する。また, 電気泳動速度の分 布については Malvern Zetasizer-F に比べ PEN KEM-3000 の方が条件に応じ鋭敏に応 答することがわかった。

c.f.c. 值は主に静置法による値を比較したが ほぼ満足すべき一致が得られた。この値を凝集 速度法及び光散乱法による值と比較すると c.f. c. 值は凝集速度法 >光散乱法 > 静圆法の順に 大きくなることがわかった。また静置法におい ては測定の際の分散粒子の濃度によってもc.f. c.は影響された。

以上のように本実験の二種類に用いたラテッ クス試料は今のところ共通試料として大きな欠 点は見あたらず，標準コロイド試料としての条 件を充分備えていることがわかった。

本研究の推進に当たり共同研究者としてゼー ター電位の測定に加わって下さった三菱化成（株）総合 研究所田川徹氏, 日本合成ゴム（株）開発研究所 笠井澄氏, 野崎産業（株）原弘氏, Gaspar de Portola 財団（バルセロナ）J. Serra 氏に対し謝意を 表します。

また本研究は文部省科学研究補助金『試験研究 (1) No. 60850148』の交付を受けて行われた。

\section{文献}

1) 界面化学部会, 界面電気測定委員会, 油化学, 19, 174 (1970)

2) 界面化学部会, 界面電気測定委員会, 油化学, 25, 239 (1976)

3) J. Lyklema, 私信 
4）西一郎，今井怡知郎，笠井正威，“界面活性剂便覽” 産業図書 (1960) p.211

5) M.S. Juang, I.M. Krieger, J. Polym. Sci., 14, 2089 (1976)

6) A. Homola, R.O. James, J. Colloid Interface Sci., 59, 123 (1977)

7) H.J. Van den Hul, J.W. Vanderhoff, J. Colloid Interface Sci,. 28, 336 (1968)

8) S.A. Troelstra, H.R. Kruyt, Kolloid-Z, 101, 182 (1946);
H.R. Kruyt, S.A. Troelstra, Kolloidchem. Beih., 54, 225 (1943)

9）北原文雄, 古沢邦夫, “分散・乳化系の化学”工業図書 (1979) p.113

10) G.J. Fleer, J. Lyklema, J. Colloid Interface Sci., 55, 228 (1976)

11) E.J.W. Verwey, J.Th.G. Overbeek, Theory of the Stability of Lyophobic Colloids, Elsevier, New York, 1948 